\title{
Whose foot is it? Pronominal Possessives in Pro-drop Languages: An Experimental Study
}

\author{
Pé de quem? Pronomes Possessivos em \\ Linguas Pro-drop: Um Estudo Experimental
}

Cilene Rodrigues

Lena Dal Pozzo*

\begin{abstract}
We present an experimental study (off-line acceptability rating task) conduced with native speakers of Brazilian Portuguese, Finnish and Italian to verify syntactic constraints on the possessive pronoun-antecedence relation in full pro-drop languages (Italian) and partial pro-drop (Brazilian Portuguese and Finnish). The goal of the investigation was to examine the hypothesis that in full pro-drop languages, null pronouns, as well as overt pronouns, are subject to principle $\mathrm{B}$, although they display a preference for local c-commanding antecedents, while in partial pro-drop languages, they respond to principle A, requiring a local c-commanding antecedent. Three factors were manipulated: type of possessive pronoun (overt vs. null), syntactic configuration regulating the intra-sentential relation between the pronoun and its antecedent (locality and c-command), the interpretation assigned to the pronoun (anaphoric, nonanaphoric and exophoric). The results suggest that the hypothesis is correct, although a significant difference between BP and Finnish was found, showing that Finns has less acceptance of non-anaphoric readings for null pronouns. As for overt pronouns, the picture is more complex, showing differences between languages and conditions. This might reflect interface issues related to recovering and evaluating antecedents.
\end{abstract}

Keywords: experimental syntax; (partial) pro-drop grammars; overt and null possessive pronouns; pronoun-antecedent relationship

\footnotetext{
* PUC-Rio

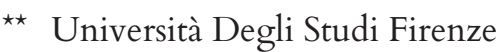


No presente artigo, apresentamos um estudo experimental (tarefa off-line de julgamento de aceitabilidade) realizado com falantes nativos de Finlandês, Italiano e Português Brasileiro, para investigar restrições sintáticas impostas à relação pronome possessivo-antecedente em línguas de pro-drop pleno (Italiano) e de pro-drop parcial (Finlandês e Português Brasileiro). O objetivo do estudo foi verificar a hipótese de que, em línguas de pro-drop pleno, pronomes nulos, assim como pronomes plenos, estão sujeitos ao princípio B da Teoria da Regência e Ligação, embora demonstrem preferência por antecedentes locais c-comandantes, enquanto em línguas de drop-drop parcial, pronomes nulos respondem ao princípio A, exigindo obrigatoriamente antecedentes locais c-comandantes. Três fatores foram manipulados: tipos de pronome (pleno e nulo), configuração sintática determinante na relação pronome-antecedente (localidade e c-comando), tipo de leitura atribuída ao pronome (anafórica, não-anafórica e exofórica). Os resultados indicam que a hipótese está correta, embora apontem para diferença significativa entre Finlandês e Português Brasileiro em relação ao pronome nulo. Quanto ao pronome pleno, a situação é mais complexa, com diferenças significativas entre as línguas e as condições. Esses resultados podem estar refletindo questões de interface na recuperação e avaliação de antecedentes.

Palavra-chave: sintaxe experimental; parâmetro pro-drop (parcial); pronomes possessivos; relação pronome-antecedente 
C. Rodrigues \&

L. Dal Pozzo

Whose foot is

it? Pronominal

Possessives

in Pro-Drop

Languages:

An experimental

study

\section{Introduction}

$\mathrm{I}$

this paper, we present an experimental study on possessive pronouns in

a full pro-drop language (Italian) and in two partial pro-drop languages (Finnish and Brazilian Portuguese (BP)).

In full pro-drop languages, there is a division of labor between overt and null pronouns: null pronouns refer preferably to c-commanding DPs, while overt pronouns take non-commanding antecedents (CALABRESE, 1986). However, this labor division is stated as matter of preference in the syntax-semantics interface: whenever a pronoun refers to a prominent entity, there is a strong preference for its null version. On the other hand, in partial pro-drop languages, null pronouns have a different grammatical status. Behaving as anaphors, they must be locally bound. Hence, in partial pro-drop languages, it seems that the contrast between overt and null pronouns is a grammatical one: null pronouns respond to Principle A of the binding theory (CHOMSKY, 1981), while overt pronouns are subject to Principle B. Thus, we have the following working hypothesis: 
(1) In full pro-drop languages, null pronouns (as opposed to overt pronouns) PREFER having local c-commanding antecedents, while null pronouns in partial pro-drop languages MUST have a local c-commanding antecedent.

This suggests that the difference between full and partial pro-drop languages is a matter of preference vs. obligatoriness of an anaphoric interpretation of null pronouns.

It has been claimed that, in syntactic and semantic research, faulty intuitions have led to false generalizations. Wasow and Arnold (2005) and others, for example, criticize non-quantitative methods used in traditional generative studies to collect data, arguing that formal theories are infested with false positives, as differences among grammatical conditions are reported although they do not really exist. Even though this criticism has been already carefully examined (SPROUSE; ALMEIDA, 2013), and may turn out to be an exaggeration, it is perhaps an instructive concern, particularly in situations in which contrasts observed among different sets of data are subtle. That is, when the line between acceptable and unacceptable is not a clear one. ${ }^{1}$

There are disagreements among linguistics with respect to the syntactic status of null pronouns in BP and Finnish, which may reflect data disagreement, as native speakers seem to have different linguistic intuitions about constraints on null pronouns. Thus, a quantitative method is recommended if one wants to measure how empirically robust are some of the generalizations presented in the literature on pronouns in pro-drop grammars.

464 We conducted an off-line acceptability-rating task to verify the validity of hypothesis (1), focusing on the syntactic status of null and overt pronominal possessives in pro-drop (Italian) and partial pro-drop (BP and Finnish) languages. ${ }^{2}$

Overall, the results show significant differences among pronouns (overt vs. null) and among languages. Null pronouns mostly recover c-commanding antecedents, while overt pronouns in general recover non c-commanding DPs. This is in accordance with hypothesis (1). However, the picture is not so straightforward, as will be discussed later on.

The paper is organized as follows: section 2 details the division of labor between overt and null pronouns; section 3 discusses null pronoun in sentential and nominal subject positions in partial pro-drop languages, and section 4 contains details of the experimental study we conducted. Section 5 presents the discussion and section 6 concludes the paper.

\footnotetext{
1 Pushing on the opposite direction, it has been claimed that acceptability judgment experimental studies might obscure the fact that each speaker has a different I-language (den DIKKEN et al., 2007), as parametric statistics rely on the mean of different judgments given by different speakers. Although this is a possibility, it is not clear that it actually happens, as discussed in Jurka (2010). Moreover many statistic programs (e.g. SPSS, used in our experiment) allow us to spot outliers and, thus, to observe the amount of variation among participants.

2 With null pronominal possessives in Finnish we refer here to the null+Px configuration. Null pronouns with no Px will not be discussed for the moment due to lack of space.
} 
C. Rodrigues \&

L. Dal Pozzo

Whose foot is

it? Pronominal

Possessives

in Pro-Drop

Languages:

An experimental study

\section{Overt and null pronouns: the division of labor}

As stated by the pro-drop parameter (CHOMSKY, 1981; RIZZI, 1986), in Italian-type languages, overt pronouns can be replaced by their null version (pro), a phenomenon often illustrated with examples like (2) and (3).

(2) Lui/pro ha trovato il libro

(Italian)

he has-3Sg brought the book

'He has brought the book'

(3) Gianni ha detto che pro/lui ha telefonato

Gianni has said-3Sg that he has-3Sg called

'Gianni said that he has called'

However, it is well known that overt and null pronouns are not freely interchangeable. Their distribution and interpretation are governed by grammatical and discourse constraints (SAITO; HOJI, 1983; PÉREZLEROUX;GLASS, 1999). Overt pronouns are more constrained than null pronouns. For instance, configurations involving co-indexation with an A-bar antecedent block overt pronouns, forcing insertion of null pronouns, (Overt Pronoun Constraint (MONTALBETTI, 1984)). As shown in (4), if a pronoun is co-indexed with a quantified DP in Spanish, it must be null. The same restriction can be observed in Japanese (SAITO;HOJI, 1983; KANNO, 1997).
(4) Nadie1 cree que *él1/ pro1 es inteligente
nobody believe-3Sg that he is-3Sg smart
'Nobody1 believes that he1 is smart'

Coreference with an antecedent in (non)argumental position seems to be constrained as well. As articulated by the Avoid Pronoun Principle (CHOMSKY, 1981), null pronouns have preference over overt pronouns whenever possible. This preference seems to be stronger in cases of coreference. For a run-ofthe-mill coreferential reading of (4), for instance, the null subject is the most suitable choice. The overt pronoun will be licensed only if it is emphasized, e.g. through focus contrastive stress.3 Calabrese (1986) refines this observation, pointing out that there is labor division between overt and null pronouns. While null pronouns are preferably used to refer back to c-commanding DPs, overt pronouns are preferably used to refer back non c-commanding DPs. This is illustrated in (5a-b), an Italian example.

Revista Letras,

3 See (12) as an example of contrastive focus.

Curitiba, UfPR, n. 96, pp.461-486,

jul./dez. 2017. ISSN 2236-0999 (versão eletrônica) 
(5) a. Quando Carlo1 ha picchiato Antonio2, pro1 era ubriaco when Carlo has-3Sg hit Antonio, was-3Sg drunk

b. Quando Carlo1 ha picchiato Antonio2, lui2 era ubriaco

when Carlo has-3Sg hit Antonio he was-3Sg drunk

'When Carlo hit Antonio, he was drunk'

Importantly, however, the division of labor among pronouns is not stated as a contrast in grammaticality, rather, it is taken to be a matter of preference in the syntax-semantics interface: whenever a pronoun refers to a c-commanding DP, there is a strong preference for its null version.

This very same preference is observed in processing. Carminati (2002), for instance, conceives it as choices of the parser when dealing with anaphora resolution. Null pronouns are preferentially interpreted as referring to syntactically prominent referents, and overt pronouns are preferentially interpreted as referring to syntactically non-prominent referents. Violating these preferences results in processing difficulty, as there is a parsing bias based on universal pragmatic principles, which state that poorer, less informative, elements should be used to retrieve discourse prominent antecedents, while richer, more informative, elements are used to retrieve less prominent antecedents.4.5

This parsing bias might reflect the size/heaviness of the internal structure of pronouns. Following Burzio (1994), one can assume that morpho-syntactic weakness induces semantic coreference, and null pronouns, being morphosyntactically weaker, are semantically and pragmatically more restrictive, preferring syntactic accessible antecedents. Cardinaletti and Starke (1999) in their typology of pronouns suggest that null pronouns, in contrast with overt pronouns, are weak forms, containing less internal structure. That is, null pronouns are smaller bundles of features, containing a subset of the features of strong pronouns, and, as such, they are reduced in structure, as represented in (6)-(7).

\footnotetext{
4 Experimental studies in Spanish confirm that pro prefers syntactically prominent antecedents, although the overt pronoun's preference for non-prominent antecedent is at chance level (ALONSO-ORVALLE et al., 2002; FILIACI, 2010). Experimental studies with L2 speakers also provide extra evidence of pro's preference for prominent antecedent (SORACE; FILIACI, 2006).

5 This is in line with accessibility models for referring choices (ARIEL, 1990), according to which speakers used different linguistic markers to refer to entities that are salient or not salient in the hearer's consciousness. As part of their linguistic knowledge, speakers organized these markers in a hierarchy of accessibility, in which definite description and stressed pronouns are low in the rank, whereas null pronouns (pro and PRO), traces and gaps are high.
} 
C. Rodrigues \&

L. Dal Pozzo

Whose foot is

it? Pronominal

Possessives

in Pro-Drop

Languages:

An experimental

study
(6)

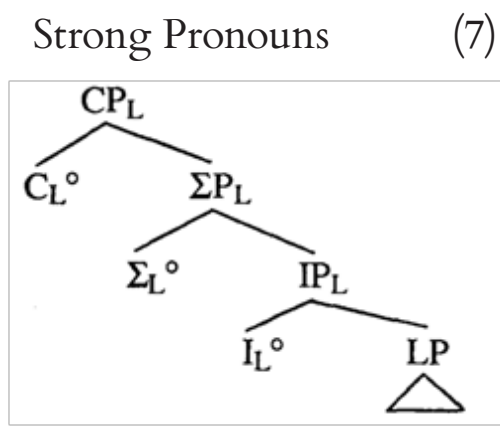

Weak Pronouns

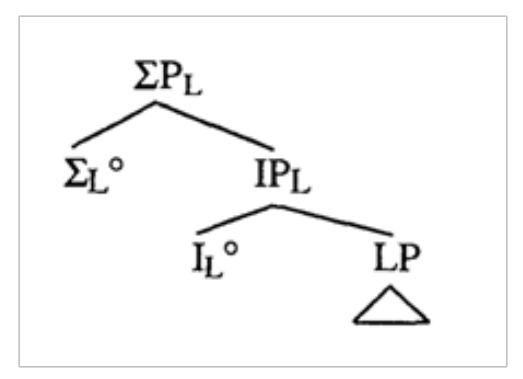

In sum, theories of grammar and theories of parsing are aligned with respect to the division of labor between null pronouns and overt pronouns. Importantly, however, this division is stated in terms of preferences: whenever a pronoun is co-indexed with a local, syntactically prominent antecedent, its null version is the preferred one. Although this seems clear, there is a methodological issue at stake here: how can preference be measured? This issue becomes evident in crosslinguistic studies, when comparative analyses are in order.

It has been claimed that in the commonly named partial pro-drop languages, null subject pronouns have a different status, behaving as anaphors, being locally bound. That is to say that we are not dealing with contrasts in preference, but rather with contrasts in grammaticality: if a null subject pronoun is not locally bound, it is not licensed. Thus, a research question is: do speakers of partial drop-languages, (as compared to speakers of bona fide drop-languages) disprefer or do not accept non-locally bound null pronouns?

\section{The status of referential null pronouns in partial pro-drop languages}

In partial null subject languages, the Avoid Pronoun Principle seems to be inoperative, as null pronouns can be freely replaced by an overt pronoun even in cases of coreference with a local antecedent (FERREIRA, 2000; RODRIGUES, 2004; HOLMBERG et al., 2009, among many others). ${ }^{6}$

(8) a. [o João $]_{1}$ disse que pro gosta da Maria (BP) the João said-3Sg that likes-3Sg of.the Maria

b. O João disse que ele ${ }_{1 / 2}$ gosta da Maria the João said-3Sg that he likes-3Sg of.the Maria 'João said he likes Maria'

Revista Letras,

Curitiba, UFPR, n. 96, pp.461-486, jul./dez. 2017. ISSN 2236-0999 (versão eletrônica)
6 The data presented in this section are mainly from Rodrigues (2004). Other sources will be acknowledged. 
(Finnish) (9) a. Jukka ${ }_{1}$ kertoi, että pro $_{1}$ oli myynyt auton Jukka-Nom said-3Sg that had-3Sg sold car-Acc

b. Jukka ${ }_{1}$ kertoi, että hän ${ }_{1 / 2}$ oli myynyt auton Jukka-Nom said-3Sg that had-3Sg sold-3Sg car-Acc 'Jukka said that he sold the car'

Also, overt pronouns are taking over in BP. In 1992, less than 30\% of sentential subject pronouns are null (DUARTE, 1995, 1996; BARBOSA et al., 2005). Hoinenen (1995) present a similar picture for colloquial Finnish, where the $1 \mathrm{Sg}$ subject pronoun minä/mä 'I' is omitted only $12 \%$ of the time.7 In addition, 3rdP referential null subjects in BP and Finnish are described as obligatory controlled pronouns, behaving like anaphors. 8 They are not licensed in matrix clauses, occurring only within embedded clauses with a local non-split c-commanding antecedent and allow only sloppy readings under VP ellipsis. (See Ferreira (2000); Rodrigues (2004); Holmberg et al. (2009); Holmberg (2016), among others). In general, there is a consensus with respect to its different behavior vis-à-vis full pro-drop languages, although there is little agreement with respect to the best theory for partial null subjects.9 Yet, there is another poorly investigated syntactic-semantic domain in which null pronouns occur: possessive DPs.

Possessive descriptions behave as argument-taking category. Relational nouns, such as those describing inherent possession, are two place-predicates, and John in (10) is the external argument (the possessor) of the possessum NP child (VERGNAUD; ZUBIZARRETA, 1992; BARKER, 1995, among others).

(10) a. John's child

b. $\quad[[\operatorname{child}]]=1 x \mathrm{l} y[\operatorname{child}(x, y)]$

A possessive pronoun can be dropped only in pro-drop languages, as exemplified in (11). This is extra evidence that inherently possessive DPs have an external subject position that has to be lexically filled. It is filled by full DPs or by null or overt pronouns, depending on the pronominal repertoire of each language.

7 The author recorded 197 cases of $1 \mathrm{Sg}$ pronominal subjects. Out of these 197 cases, only 23 were cases of subject omission, and 5 of them were replies to answers.

8 In this paper, there is not need to discuss any version of Binding theory in detail. The version proposed in Chomsky (1981) is enough for our purpose.

9 At least three different analyses have been already considered for referential null subjects in partial pro-drop languages: (i) they are bound variables (MODESTO, 2000); (ii) they are residues of A-movement (FERREIRA, 2000; RODRIGUES, 2004); (iii) they are elided NPs (BARBOSA, 2014). Although each of these proposals deserve to be carefully considered, doing so is beyond the scope of the present study, and deciding which one is the best theoretically speaking might hinge on issues still unresolved within the Minimalist Program, as the syntactic and semantic status of theta-roles. 
C. Rodrigues \&

L. Dal Pozzo

Whose foot is

it? Pronominal

Possessives

in Pro-Drop

Languages:

An experimental study

(11) a. Juan se encontró con [el pro primo]

(Spanish)

Juan SE met-3Sg with the cousin

'Juan met with his cousin'

b. John met with *(her) brother

However, in full pro-drop languages, possessive pronouns, similarly to sentential subject pronouns, are constrained by the Avoid Pronoun Principle. Coreferential strong possessive pronominal forms, ${ }^{10}$ such ella in Spanish (12), are allowed only when it is marked with emphatic, contrastive stress:

$$
\begin{aligned}
& \text { María1 ama al novio de ELLA1, no al de Ana. } \\
& \text { Maria love-3Sg to.the boyfriend of she, not to.the the Ana } \\
& \text { 'Maria loves HER boyfriend, not Ana's boyfriend' }
\end{aligned}
$$

Given the substantial change observed in partial pro-drop languages, it is expected that the Avoid Pronoun Principle does not apply to possessive pronouns in these grammars. Silva (1984) and Cerqueira (1996) observe that BP is loosing weak pronominal forms (including null pronouns, see (13a-b), which are being replaced by strong forms like (13c). Note that the pronoun ela in (13c) may not be emphatic or contrastive.
a. [a Maria 1 gosta $\mathrm{d}[\mathrm{o} \quad$ seu1 pai $]$ the Maria like-3Sg of.the her father
b. [a Maria $]$ gosta $\mathrm{d}[\mathrm{o}$ pro1 pai $]$ the Maria like-3Sg of the father
c. [a Maria $] 1$ gosta $\mathrm{d}[\mathrm{o}$ pai dela1] the Maria like-3Sg of.the father of.she 'Maria likes her father'

In addition, null possessive pronouns in BP display obligatory controlled properties (RODRIGUES, 2004; RODRIGUES, 2010; FLORIPI; NUNES. 2009): a local commanding non-split antecedent is required (14a-d), and only a sloppy reading is available under VP ellipsis (14e). It might be important to emphasize that only relational readings of the possessive nouns in (14) are to be linked to the syntactic presence of an obligatory controlled null pronoun.

(14) a. [o João]1 encontrou [o pro1/ ${ }^{\star} 2$ irmão $]$ the João met the brother 'João met his own brother'

b. * [a cobra [do João]1] mordeu [ o pro1 braço] the snake of.the João bit-3Sg the arm

Revista Letras,

Curitiba, UFPR, n. 96, pp.461-486, jul./dez. 2017. ISSN 2236-0999 (versão eletrônica) 
c. * [a mulher] 1 disse que [o médico] 2 vai operar [o pro1 útero] the woman said-3Sg that the doctor will-3Sg operate the uterus

d. *[a Maria]1 falou para [o Paulo]2 que encontrou [a pro1+2 mãe] the Maria said-3Sg to the Paulo that met-3Sg the mother

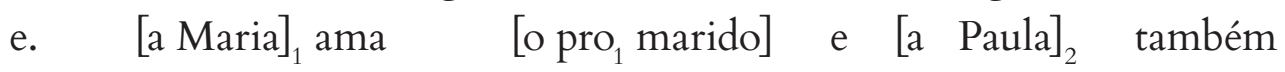
the Maria love-3Sg the husband and the Paula too

'Maria loves her husband and Paulo does too'

(=Paula loves her own husband)

The empirical correctness of these data is still to be confirmed, however, as there are speakers who claim to accept non-local and split antecedents, and strict readings under VP ellipsis. This variation, as we will discuss later, might be a reflex of grammatical variation among speakers.

In Finnish, the picture is a bit more complex, as there are three ways of structuring a possessive DP: an overt possessive pronoun followed by a noun plus an agreeing possessive suffix $(\mathrm{Px}),{ }^{11}(15 \mathrm{a})$, a null pronoun followed by a noun with a Px (15b), and just a bare noun (15c). Notice that overt pronouns cannot occur in (15c). Our hypothesis is that nouns with no agreeing possessive suffix are not relational. Hence, they do not require an external argument (i.e. a possessor). ${ }^{12}$ As for nouns followed by $\mathrm{Px}$, we assume them to be two-place predicates, whose external argument is either an overt pronoun or a null pronoun.

(15) a. Pekka näkee hänen ystävä-nsä

Pekka see-3Sg his/her friend-3Px

470

b. Pekka näkee ystävä-nsä

Pekka see-3Sg friend-3Px

c. Pekka näkee ystävän

Pekka see-3Sg friend

'Pekka sees her friend'

DPs with no Px (15c) haven't received much attention, but DPs containing Px have been carefully analyzed and there seems to be no consensus with respect to the syntactic and semantic status of the possessor in examples like (15b). Some researchers take it to be anaphoric (PIERREHUMBERT, 1980; VAINIKKA, 2011), while others argue that they behave as pronouns (HUHMARNIEMI; BRATTICO, 2015).

In sum, while the empirical description of sentential subject pronouns seems to be well accepted, pointing towards substantial differences between full pro-drop and partial pro-drop languages, the grammatical status of pronominal possessives in pro-drop languages is less clear. First, the literature on possessives is in general

11 Px is a morphological realization of agreement with the possessor, see Pierrehumbert (1980) and Vainikka (1989).

12 Data from Toivonen (2000). 
C. Rodrigues \&

L. Dal Pozzo

Whose foot is

it? Pronominal

Possessives

in Pro-Drop

Languages:

An experimental study

sparse; second there is no consensus with respect to the anaphoric nature of null possessive pronominal forms in partial drop-languages. Nevertheless, assuming that a change in the pro-drop parameter would affect all the domains in which pronouns are licensed, we would expect sentential and nominal pronominal subjects to behave alike.

A hallmark of an anaphor is its dependency on a local c-commanding antecedent. Thus, our research goal was investigating this dependency for both overt and null possessive pronouns, trying to measure how strong it is in full pro-drop and in partial pro-drop grammars (hypothesis (1)).

\section{Testing overt \& null pronouns cross-linguistically}

\subsection{Experimental design}

The experimental task designed to verify the hypothesis stated in (1) consists of an acceptability judgment task, which was conducted online (onlinepesquisa -www.onlinepesquisa.com). The speakers' task was evaluating our interpretations/answers for each of the sentences they read, using a 5-point Likert scale $(0-4,0=$ the worst answer, $4=$ the best answer $) .{ }^{13}$ Importantly, it was explicitly said that more than one interpretation/answer could receive the same evaluation. ${ }^{14}$

Three factors were manipulated (see Table 1): type of pronoun, the syntactic configuration regulating the relationship between the pronoun and its possible antecedent, the type reading assigned to the pronoun (anaphoric, non-anaphoric, exophoric). The variable language was a group factor. The dependent variable was the score assigned each reading.

\begin{tabular}{|c|c|c|c|}
\hline \multicolumn{4}{|c|}{ Possessive Pronoun } \\
\hline Language & Type of Pronoun & Syntactic configuration & $\begin{array}{l}\text { Pronominal } \\
\text { interpretation }\end{array}$ \\
\hline $\mathrm{BP}$ & \multirow{3}{*}{$\begin{array}{l}\text { Overt } \\
\text { Null }\end{array}$} & \multirow{3}{*}{$\begin{array}{l}\text { C-Command } \\
\text { Locality }\end{array}$} & \multirow{3}{*}{$\begin{array}{l}\text { Anaphoric } \\
\text { Non-anaphoric } \\
\text { Exophoric }\end{array}$} \\
\hline Finnish & & & \\
\hline Italian & & & \\
\hline
\end{tabular}

Table 1. The experimental design

Revista Letras,

Curitiba, UFPR, n. 96, pp.461-486, jul./dez. 2017. ISSN 2236-0999 (versão eletrônica)

13 To us it seems more intuitive assigning a 0 (zero), rather than 1 (one), to an interpretation that is not acceptable at all. Hence, we used a 0-4 scale, although most of the Likert scales used in the field start in 1.

14 A reviewer commented that an optional experiment with participants ranking linearly (from better to worse) all the possible readings might be a more transparent way of measuring preference. We are not sure about this, as the proposed task would not let us see if two readings are equally acceptable or not. 
The target pronouns were provided with 2 possible intra-sentential antecedents. In the locality condition (16), both antecedents c-commanded the pronoun, but only one of them was within the same sentential domain as the pronoun. In the c-command condition (17) only one of the possible antecedents c-commanded the pronoun, but both of them were within the same sentential domain as the pronouns:

$$
\begin{aligned}
& \text { Locality condition: }\left[\mathrm{S}_{\mathrm{S}} \mathrm{A}_{1} \ldots\left[{ }_{\mathrm{S}} \mathrm{A}_{2} \ldots \mathrm{PRON}\right]\right] \\
& \text { C-Command condition: } \left.\left[_{S}\left[{ }_{\mathrm{DP}} \mathrm{A}_{1} \ldots\left[\mathrm{A}_{2}\right]\right] \ldots \text { PRON }\right]\right]
\end{aligned}
$$

For each language, there were, thus, 4 conditions in total, which we summarize in (18). For each sentence, four possible interpretations/readings of the pronoun were provided: anaphoric, non-anaphoric, exophoric, and split antecedent. The split antecedent reading, however, was not computed. It acted as a controller for the correct execution of the task, given that it induces a number mismatch in the full pronoun condition. ${ }^{15}$

$$
\text { Experimental conditions: }
$$

a. Null pronoun, C-command

Se eu digo: a amiga da Tigrinha lavou o pé machucado, de quem é o pé que foi lavado?

'If I say: Tiger Lily's friend washed the injured foot, whose foot was washed?'

b. Overt pronoun, C-command

Se eu digo: o filho do indio sabichão cortou o cabelo dele, de quem é o cabelo que foi cortado?

'If I say: the son of the wise indian cut his hair, whose hair was cut?'

c. Null Pronoun, Locality

Se eu digo: o Capitão Gancho afirmou que o Peter Pan cortou o dedo, de quem é o dedo que foi cortado?

'If I say: Captain Hook said that Peter Pan cut the finger, whose finger was cut?'

d. Overt Pronoun, Locality

Se eu digo: a Sininho afirmou que a Tigrinha cortou o dedo polegar dela, de quem é o dedo que foi cortado?

'If I say: Tinker Bell said that Tiger Lily cut her thumb, whose finger was cut?'

15 The overt pronoun was always singular. Different studies have shown that mismatch in formal features (e.g. gender and number) have an immediate effect on processing the pronoun (CHOW; LEWIS; PHILLIPS, 2014). Hence, under the overt pronoun condition, speakers were expected to assign zero to the split antecedent interpretation because this reading induces number mismatch. 
C. Rodrigues \&

L. Dal Pozzo

Whose foot is

it? Pronominal

Possessives

in Pro-Drop

Languages:

An experimental study

(19) Example of how each task item was presented to participants.

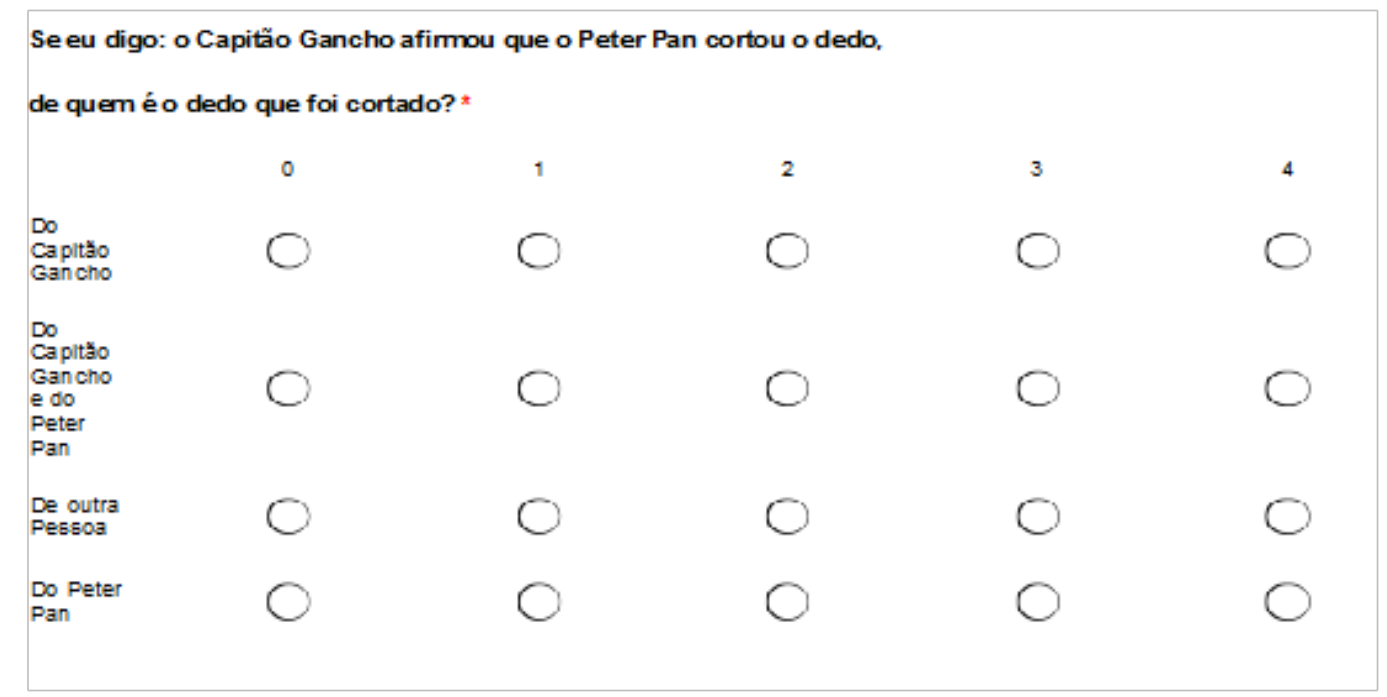

All the target items involved inalienable possession and the antecedents were either definite DPs or proper names, and they match the pronoun in semantic and formal features. We also controlled for the semantic and pragmatic plausibility of each antecedent.

\subsection{Material}

The experiment consisted of 48 experimental items: 24 target-items (6 items per condition) and 24 fillers. The presentation of the stimulus was preceded by 3 training/warm up items, which, similar to the fillers, consisted of scopal interaction among quantifiers, VP ellipsis and definiteness.

All the items and the four possible readings assigned to each item were presented in a randomized order per participant. In Finnish, 12 items more were included to contemplate all the syntactic configurations inalienable possession (Overt Pronoun + NPx, Null Pronoun + NPx, bare nouns), see discussion in section 3.

At the end of the task, participants also answered a sociolinguistic questionnaire about age, sex, place of birth, place of residence, language disorders in the family etc. This informed us about possible dialectal variation and cases of language disorder that could affect the results.

\subsection{Participants}

Adult native speakers were recruited through social media in Brazil, Italy and Finland. Table 2 provides the main information about participants. ${ }^{16}$

Revista Letras,

16 We are reporting here only the data of the participants who completed the questionnaire.

Curitiba, UfPR,

n. 96, pp.461-486,

jul./dez. 2017.

ISSN 2236-0999

(versão eletrônica) 


\begin{tabular}{|c|c|c|c|c|}
\hline & $\begin{array}{l}\mathbf{B P} \\
n=103\end{array}$ & & $\begin{array}{l}\text { Italian } \\
n=54\end{array}$ & $\begin{array}{l}\text { Finnish } \\
n=67\end{array}$ \\
\hline Age range (mean) & $18-30$ & & $18-30$ & $18-30$ \\
\hline Sex & $\begin{array}{l}\mathrm{F}=73,8 \% \\
\mathrm{M}=26,2 \%\end{array}$ & & $\begin{array}{l}\mathrm{F}=60,8 \% \\
\mathrm{M}=39 \%\end{array}$ & $\begin{array}{l}\mathrm{F}=88 \% \\
\mathrm{M}=12 \%\end{array}$ \\
\hline $\begin{array}{l}\text { Language disorders in the } \\
\text { family }\end{array}$ & $0,9 \%$ & & $5,8 \%$ & -- \\
\hline Education level & $\begin{array}{l}\text { MA degree or } \\
\text { more } 56 \% \\
\text { Undergr./College } \\
34 \% \\
\text { High school 7,8\% } \\
\text { Less than high } \\
\text { school 0,9\% }\end{array}$ & $\begin{array}{l}\text { MA degree or } \\
\text { more } 64,7 \% \\
\text { BA degree } \\
15,7 \% \\
\text { High school } \\
19,6 \% \\
\text { Less than high } \\
\text { school -- }\end{array}$ & \multicolumn{2}{|c|}{$\begin{array}{l}\text { MA degree or more } 46,3 \% \\
\text { BA degree } 31,3 \% \\
\text { High school } 9,4 \% \\
\text { Less than high school } 2,9 \%\end{array}$} \\
\hline
\end{tabular}

Table 2. Participants' sociolinguistics data

The three groups were quite homogeneous, and participants were from different regions of the three countries: ${ }^{17}$

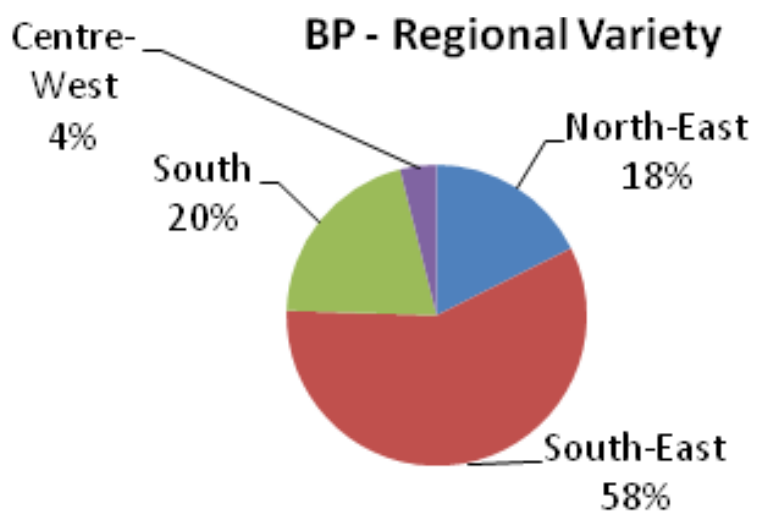

Graph 1: Distribution of participants for Brazilian Portuguese

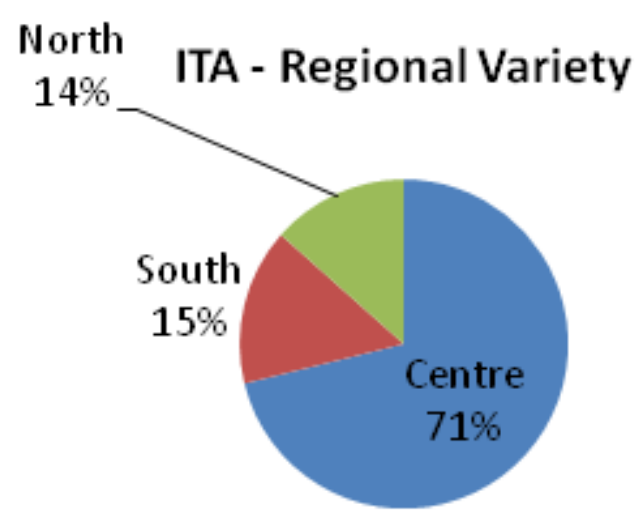

\section{Graph 2: Distribution of participants for Italian}

17 Each participant in the three groups also answered the question do People recognize you as a speaker of which region? These, together with information about place of birth and place of residence, helped us classifying the participants in terms dialects. 
C. Rodrigues \&

L. Dal Pozzo

Whose foot is

it? Pronominal

Possessives

in Pro-Drop

Languages:

An experimental study

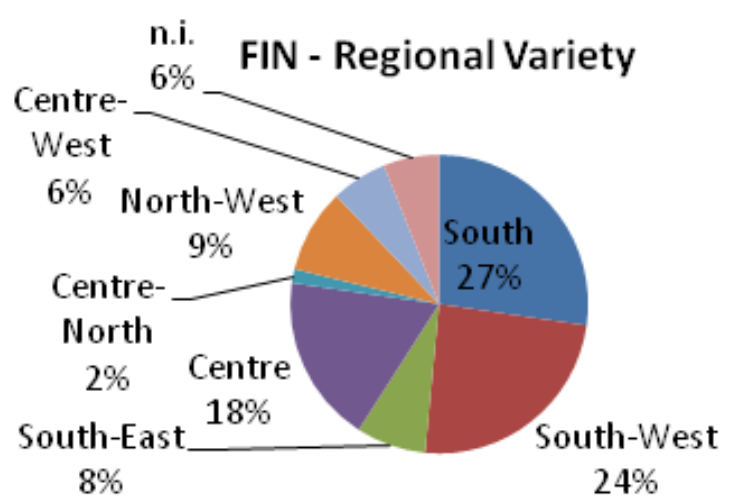

\section{Graph 3: Distribution of participants for Finnish}

\subsection{Results}

A within subject repeated measures ANOVA reveals that there is a significant difference between pronouns when the three languages are grouped together $(p=.001)$, graph 4$): 18,19$ null pronouns trigger anaphoric interpretations, whereas overt pronouns trigger non-anaphoric interpretations.
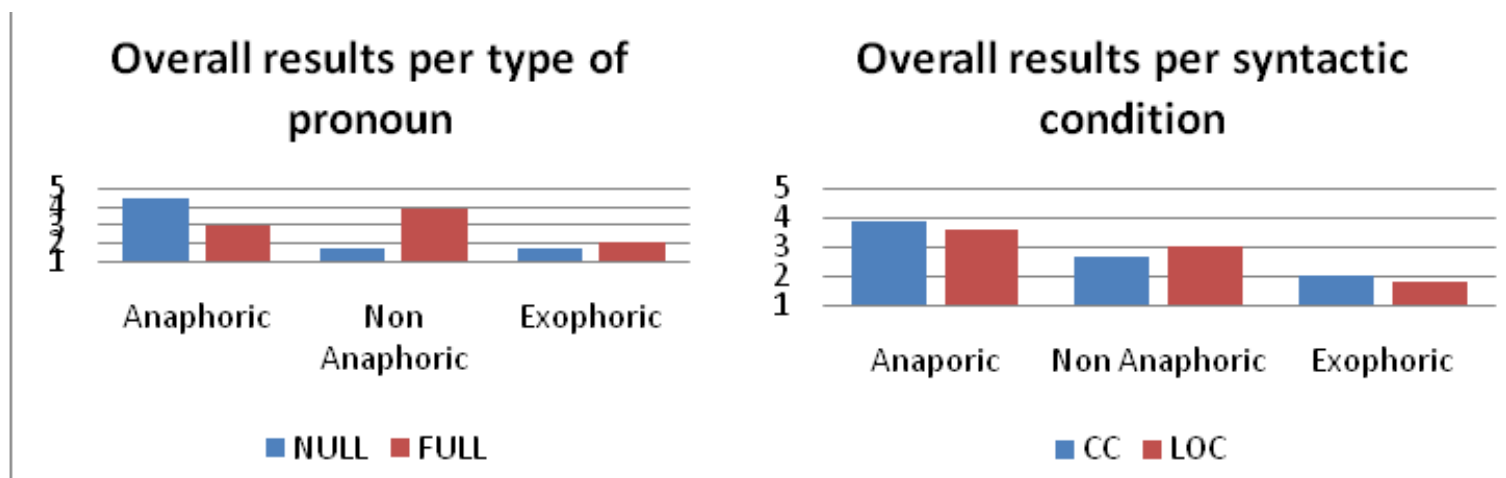

Graphs 4 \& 5: Overall results for BP, Finnish and Italian computed altogether

The syntactic configuration (C-command and Locality) does not affect the interpretation of null pronouns. However, it plays a role in the interpretation of overt pronouns $(p=.001)$. Speakers of the three languages assigned a higher value to the non-anaphoric reading for overt pronouns under the locality condition. However, in the c-command condition, the judgments varied: Brazilians assigned either an anaphoric or non-anaphoric readings to overt pronouns, Italians preferred the anaphoric reading, while Finns significantly preferred the non-anaphoric one. Graphs below summarize the results:

Revista Letras,

18 The statistics was run in SPSS program.

19 In the graphics, the vertical axis refers to the values assigned to the interpretations listed in the horizontal axis. Participants used a 0 to 4 Likert scale to express their judgments, but the onlinepesquisa platform handled the results to us organized in a 1 to 5 scale. This had no negative or positive impact on the final results.

Curitiba, UFPR, n. 96, pp.461-486, jul./dez. 2017. ISSN 2236-0999 (versão eletrônica) 

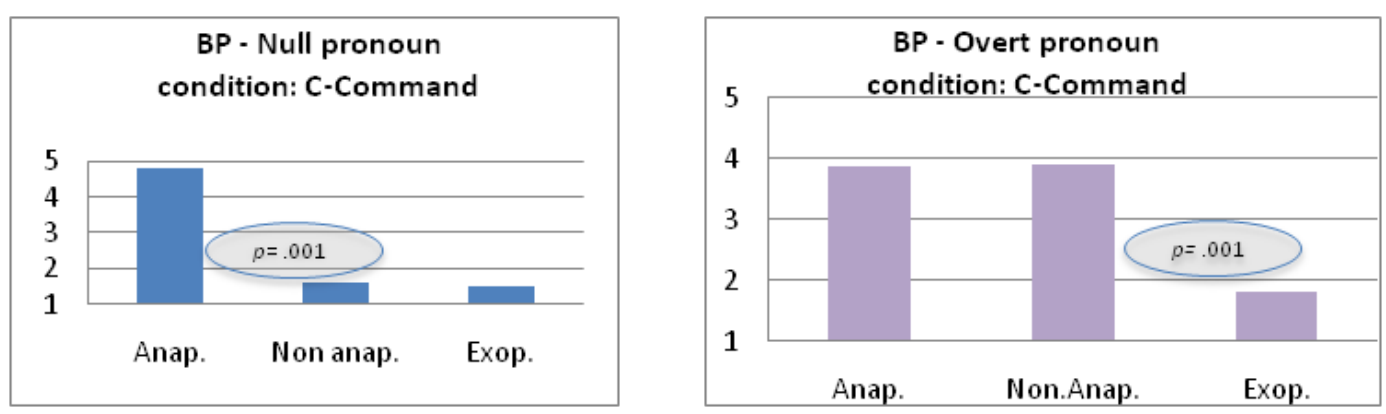

Graphs 6 \& 7: Results for BP under the C-command condition
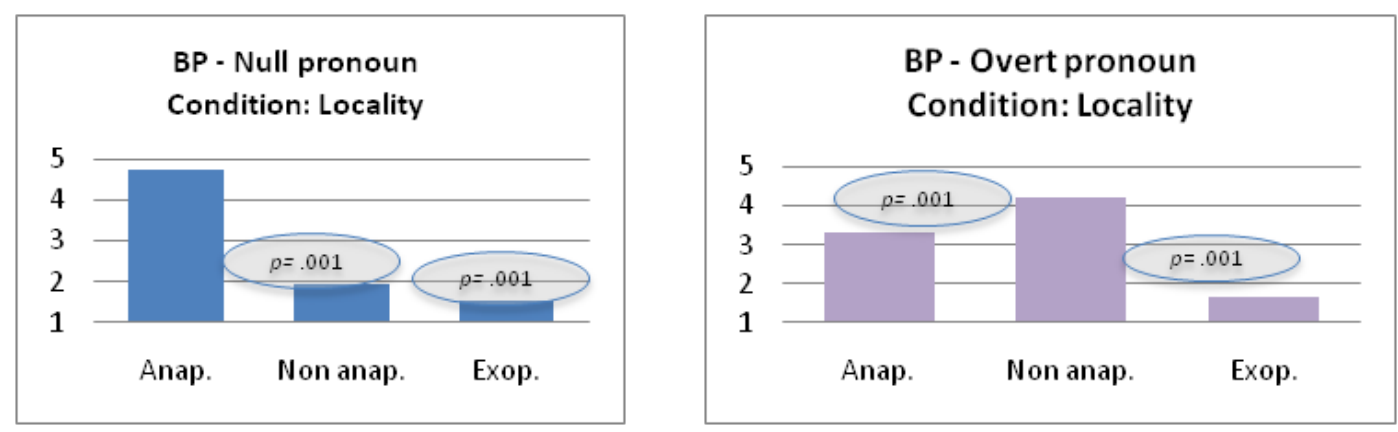

Graphs 8 \& 9: Results for BP under the Locality condition
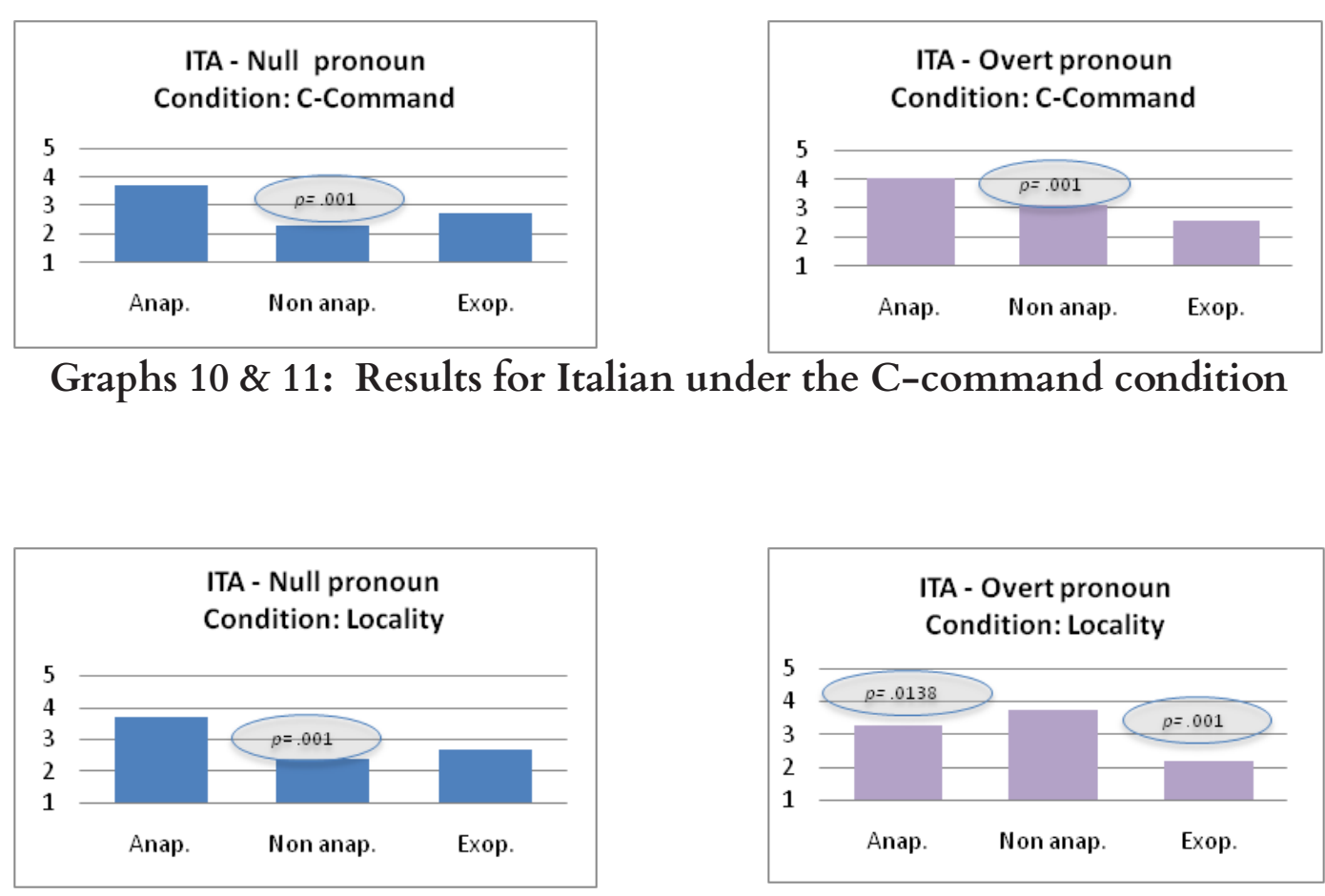

Graphs 10 \& 11: Results for Italian under the C-command condition

Graphs 12 \& 13: Results for Italian under the Locality condition
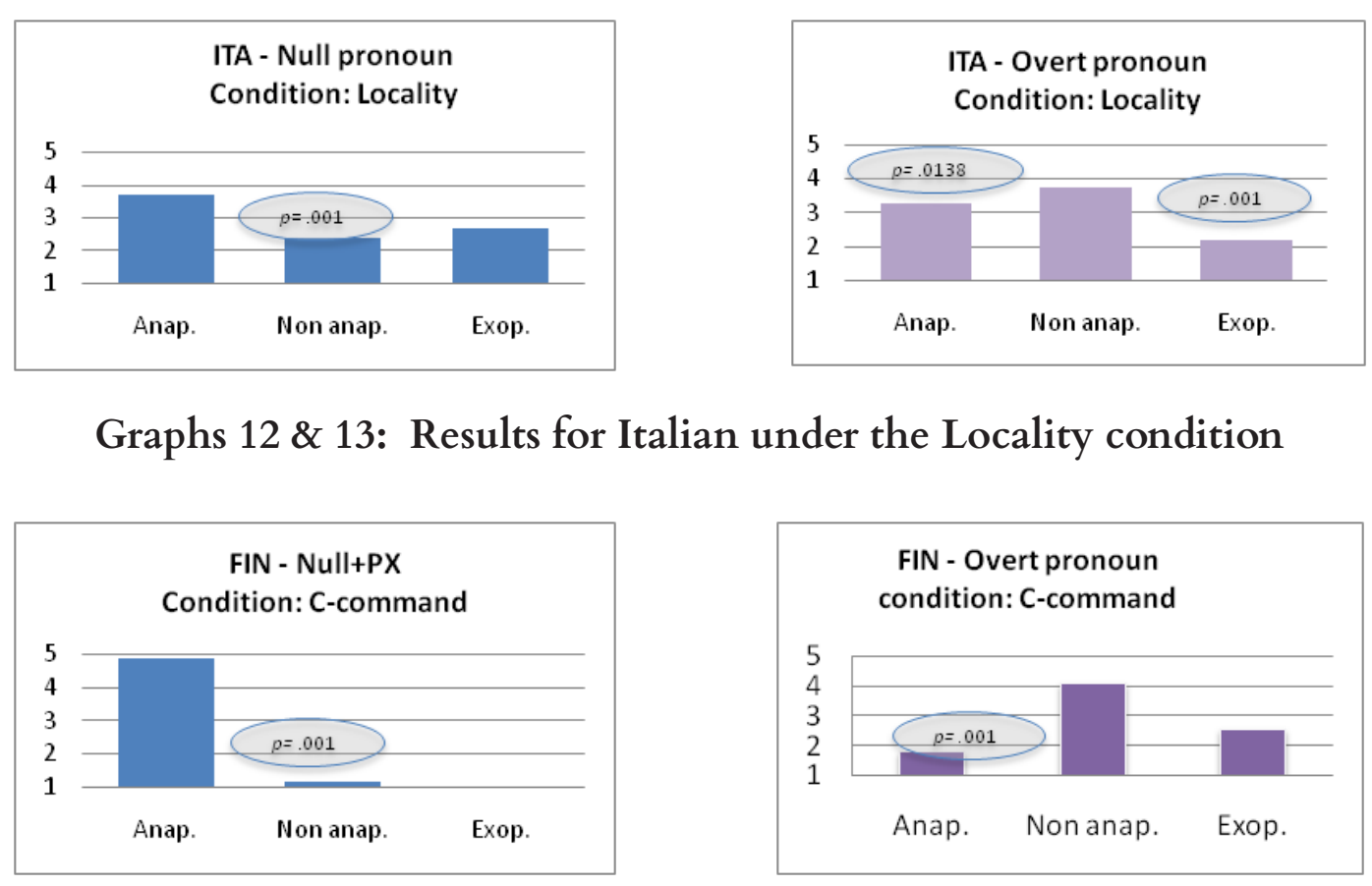

Graphs 14 \& 15: Results for Finnish under the C-command condition 
C. Rodrigues \&

L. Dal Pozzo

Whose foot is

it? Pronominal

Possessives

in Pro-Drop

Languages:

An experimental study
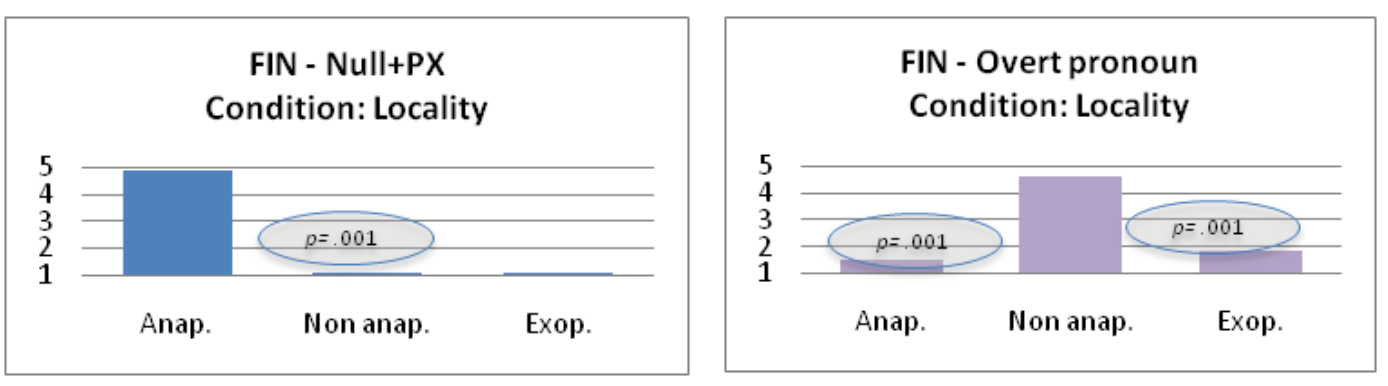

\section{Graphs 16 \& 17: Results for Finnish under the Locality condition}

A closer look at each language separately is also revealing. In BP, under the c-commanding condition, the antecedent of null possessive pronouns has to be a local c-commanding DP. Overall Brazilians assigned a very low grade to non-anaphoric readings of null pronouns. As show on table 3 , the mean of the scores assigned to non-anaphoric reading is below 2.0. However, with overt pronouns things are not clear. The preference for the antecedent fluctuates between the anaphoric and the non-anaphoric options, with a non-significant preference for the anaphoric interpretation. ${ }^{20}$ The exophoric reading ('another person') is excluded both with null and overt pronouns.

$\begin{array}{lll}\text { Pronoun } & \text { Reading } & \text { Mean } \\ \text { Null } & \text { Anap. } & 4,82 \\ \text { Null } & \text { Non anap. } & 1,61 \\ \text { Null } & \text { Exop. } & 1,52 \\ \text { Overt } & \text { Anap. } & 3,88 \\ \text { Overt } & \text { Non anap. } & 3,91 \\ \text { Overt } & \text { Exop. } & 1,82\end{array}$

Table 3. Score means in C-Command condition in BP

In the Locality condition, the results for null possessives are as clear as in the c-command condition: the local antecedent (anaphoric reading) is overwhelmingly preferred. As for overt pronouns, even though the local antecedent is not totally excluded, non-local antecedents (non-anaphoric reading) are the preferred options $(t(101)=10,55 p=.001)$. Again, the exophoric reading was disregarded.

$\overline{20(\mathrm{t}(101)=1,40} \quad p=.1651)$
Revista Letras,

Curitiba, UfPr, n. 96, pp.461-486, jul./dez. 2017. ISSN 2236-0999 (versão eletrônica) 


$\begin{array}{lll}\text { Pronoun } & \text { Reading } & \text { Mean } \\ \text { Null } & \text { Anap. } & 4,74 \\ \text { Null } & \text { Non anap. } & 1,95 \\ \text { Null } & \text { Exop. } & 1,56 \\ \text { Overt } & \text { Anap. } & 3,30 \\ \text { Overt } & \text { Non anap. } & 4,21 \\ \text { Overt } & \text { Exop. } & 1,67\end{array}$

Table 4. Score means in Locality condition in BP

No statistical differences were observed among the different subgroups of the regional varieties.

In Italian, null pronouns are more tolerant to non-anaphoric readings. Although the means for this reading are below 2.5, it is above 2 (see Graphs $5-6)$. This significantly contrasts with BP $(p=.034)$. The exophoric reading is excluded, even though the exclusion was not as straightforward as in BP. ${ }^{21}$ The contrast between BP and Italian is not significant under the overt pronoun condition ( $\mathrm{p}=.0138$ ), even though in the c-command condition, while Brazilians allow both anaphoric and a non-anaphoric readings, Italians present a preference for the anaphoric reading.

$\begin{array}{lll}\text { Pronoun } & \text { Reading } & \text { Mean } \\ \text { Null } & \text { Anap. } & 3,70 \\ \text { Null } & \text { Non anap. } & 2,31 \\ \text { Null } & \text { Exop. } & 2,71 \\ \text { Overt } & \text { Anap. } & 4,04 \\ \text { Overt } & \text { Non anap. } & 3,09 \\ \text { Overt } & \text { Exop. } & 2,55\end{array}$

Table 5. Score means in C-Command condition in Italian

21 This might be due to avoidance of reflexive verbs, commonly used in Italian in these contexts. We chose to use only possessive pronouns ((ia) vs. (ib)) (ha lavato la sua mano vs. si è lavato la mano 'he washed his hand') as an attempted to make the experiment uniform among the three language investigated.

a. Ha lavato la sua mano has washed the his/her hand

Si è lavato la mano

REFL is washed the hand

'He/she washed his/her hand' 
C. Rodrigues \&

L. Dal Pozzo

Whose foot is

it? Pronominal

Possessives

in Pro-Drop

Languages:

An experimental

study

$\begin{array}{lll}\text { Pronoun } & \text { Reading } & \text { Mean } \\ \text { Null } & \text { Anap. } & 3,69 \\ \text { Null } & \text { Non anap. } & 2,36 \\ \text { Null } & \text { Exop. } & 2,67 \\ \text { Overt } & \text { Anap. } & 3,27 \\ \text { Overt } & \text { Non anap. } & 3,71 \\ \text { Overt } & \text { Exop. } & 2,20\end{array}$

Table 6. Score means in Locality condition in Italian

In Finnish, bare nouns are exophoric in all conditions and will not be further discussed at present. In the c-command and in the locality condition, $[$ Null Pronoun $+P x]$ present an overwhelming preference for the anaphoric reading, while $[$ Overt Pronoun $+P x]$ had a preference for the non-anaphoric readings. Note, however, that under the c-command condition, the exophoric reading is not totally excluded for overt pronouns.

\begin{tabular}{|c|l|l|}
\hline Pronoun & Reading & Mean \\
\hline$N u l l+P x$ & Anap. & 4,89 \\
\hline$N u l l+P x$ & Non anap. & 1,13 \\
\hline$N u l l+P x$ & Exop. & 1,02 \\
\hline Overt $+P x$ & Anap. & 1,83 \\
\hline Overt $+P x$ & Non anap. & 4,14 \\
\hline Overt $+P x$ & Exop. & 2,57 \\
\hline
\end{tabular}

Table 7. Scores' means in C-Command condition in Finnish

\begin{tabular}{|c|l|l|}
\hline Pronoun & Reading & Mean \\
\hline$N u l l+P x$ & Anap. & 4,92 \\
\hline$N u l l+P x$ & Non anap. & 1,08 \\
\hline$N u l l+P x$ & Exop. & 1,05 \\
\hline Overt $+P x$ & Anap. & 1,51 \\
\hline Overt $+P x$ & Non anap. & 4,64 \\
\hline Overt $+P x$ & Exop. & 1,82 \\
\hline
\end{tabular}

Table 8. Scores' means in Locality condition in Finnish. 


\section{Discussion}

The results presented above can be summarized in the following way:

(i) Null pronouns are significantly anaphoric in BP, Finnish and Italian.

(ii) However, when the three languages are compared among themselves, they are significantly different with respect to the interpretation of null pronouns. Italians have more tolerance than $\mathrm{BP}$ and Finnish for nonanaphoric readings, but Brazilians assigned significant higher scores for non-anaphoric readings than Finns. Finnish was, therefore, the less tolerant grammar for non-anaphoric readings of null possessive pronouns.

(iii) Overt pronouns in the Locality condition presented a significant preference for non-anaphoric readings in the three languages under investigation.

(iv) Contrastively, in the c-command condition, the interpretation of overt pronouns showed more variability: Brazilians assigned either anaphoric or non-anaphoric readings; Italians interpreted them as being anaphoric and Finns understood them as mainly being non-anaphoric but exophoric readings were not straightforwardly excluded. ${ }^{22}$

Given the discussion presented in sections 2 and 3, our general results for null pronouns were expected. In accordance with hypothesis (1), in Italian null pronouns have a strong preference for prominent antecedents, but nonprominent antecedents are not completely excluded, being probably acceptable when favored pragmatically. This corroborates with the division of labor observed in Italian (CALABRESE, 1986; CARMINATI, 2002). Contrastively, in Brazilian and Finnish null pronouns have less tolerance for non-anaphoric interpretations. Thus, our results are aligned with theoretical proposals according to which null pronouns in partial pro-drop languages are anaphors, subject to principle A of Binding theory (RODRIGUES, 2004; FLORIPI; NUNES, 2009; HOLMBERG et al., 2009). Crucially, these results provide evidence against Huhmarniemi and Brattico (2015), who claim that Finnish null possessives are pronouns, dispensing with local c-commanding antecedents.

Although this needs to be further investigated, the significant difference between BP and Finnish with respect to assignment of non-anaphoric interpretations to null pronouns might be due to dialect variation and level of education among Brazilians, who might be speakers of standard Brazilian Portuguese, which is more similar to European Portuguese.

22 It was possible that speakers understood the pronouns as being emphatic, giving us an unexpected results (Adam Albright, pc.). Thus, we did a follow-up in Italian with overt pronouns using audio files. The sentences were all pronounced neutrally without any emphatic stress on the target items. Emphasis did not present itself as significant. Thus, the possibility of an emphatic reading of the pronouns does seem to be playing a role here. 
C. Rodrigues \&

L. Dal Pozzo

Whose foot is

it? Pronominal

Possessives

in Pro-Drop

Languages:

An experimental study

Revista Letras,

Curitiba, UFPR,

n. 96, pp.461-486,

jul./dez. 2017. ISSN 2236-0999

(versão eletrônica)

An unexpected finding was the contrast regarding the syntactic configurations in which overt pronouns are bound.

The literature on the acquisition of overt pronouns shows that children, differently from adults, allow overt pronouns to be locally A-bound (CHIEN; WEXLER, 1999; GROLLA, 2010; COSTA; AMBULATE, 2010, among others).23 Our results suggest that adults also have problems in computing the antecedent of overt pronouns in structures involving c-command. One possible way of unifying our findings with observations about the acquisition of Principle B is through the Competing Computations theory (REINHART 1999, 2006; GROLLA, 2010). Reinhart proposes that every time the output of the syntactic component is not sufficient for the interfaces needs, a reference-set is generated. This set contains all possible structural outcomes (i.e. pairs of derivations and interpretation) based on the same initial numeration. Against this set, the actual syntactic output is evaluated and a decision is taken. This evaluation is, thus, an interface strategy that, according to Reinhart, leads to processing difficulties because the process of creating a reference set and comparing each member of it with the actual structure might lead to working memory overloading. Grolla (2010) applied this line of reasoning to the acquisition of overt pronouns and assumed with Hornstein $(2001,2007)$ that pronouns are elsewhere elements inserted into the derivation at the interfaces to guarantee convergence, implicating more costly derivations. Thus, children have difficulties with principle $\mathrm{B}$ because structures with pronouns involve the process of competing computations to verify whether or not a cheaper structure (e.g. one in which movement applies) could be possible. A similar issue might underline adults' problems with overt pronouns under the c-command condition.

Taking for granted that the cost of a given derivation is a function of the amount of features that has to be manipulated at the interfaces, Hornstein's suggestion that derivations with movement is cheaper than derivations with pronoun insertion can be recast in the following way: movement is cheaper because it involves copies with no PF features, while pronouns have PF features. Thus, pronouns increase the load of features that has to be computed during the course of the derivation. This also means that in pro-drop languages, the Avoid Pronoun Principle (see Section 2) should apply at the interfaces, blocking overt pronouns whenever insertion of a null pronoun is an option, as overt pronouns has more structure/features than null pronouns (CARDINALETTI; STARKE, 1999).

If this analysis is on the right track, the difficulty adults speakers of BP, Italian and Finnish encountered in interpreting overt pronouns in the c-command condition is not due to any grammatical restriction, being rather a reflex of interface issues. In this condition, the two possible antecedents are retrieved from memory probably in only one chunk, as one is contained inside

23 Chien and Wexler (1999), among others, show that children (age-ranging from 4 to 5) behave at chance level, assuming local antecedents to overt pronouns around $50 \%$ of the time. 
the other. This leads to a computing cost as a null pronoun could be used to refer the most prominent antecedent. In the locality condition, since the two are retrieved independently, choosing the non-local antecedent does not involve an evaluation on the interfaces. That is, in the locality condition, pronoun resolution does not trigger the process of evaluating competing computations, being therefore, lighter (as compared to the c-command condition), in terms of interface evaluation.

\section{Final Remarks}

First, this paper underscores the importance of using experimental methods to investigate the syntactic and semantic status of null pronouns in full and partial pro-drop languages, as it shows that the difference between full and partial pro-drop language with respect to the licensing of null pronouns might be too tenuous to be measured informally. It also shows that partial pro-drop grammars may not be completely alike in their restrictions on the interpretations of null pronouns. Although both BP and Finnish have been analyzed as displaying the same syntactic requirements on null pronouns, the results of our experiment indicate that they are significantly different with respect to null possessive pronominal forms, a fact that needs to be further investigated taking into consideration the many different dialects that compose the so-called Brazilian Portuguese language. As for overt pronouns, there is a high preference for non-local antecedents (non-anaphoric readings) in bi-clausal structures. However, in mono-clausal structures in which c-command is the structural condition on possible antecedents, the resolution of the pronounantecedent relation is not straightforward. This, as we discussed, might result from difficulties in recovering and evaluating the antecedents in structures in which one antecedent is embedded within the other. 
C. Rodrigues \&

L. Dal Pozzo

Whose foot is

it? Pronominal

Possessives

in Pro-Drop

Languages:

An experimental study
ALONSO-OVALLE, L.; FERNÁNDEZ-SOLERA， S.; FRAZIER， L.; CLIFTON, C. Null and overt pronouns and the topic-focus articulation in Spanish. Journal of Italian Linguistics, v. 14, n. 2, p. 151-169, 2002.

AOUN, J.; LI, Y.-H. A. Minimal disjointness. Linguistics, v. 28, p. 189-204, 1990.

AOUN, J.; HORNSTEIN N. Bound and referential pronouns. In: HUANG, C.-T. J.;MAY, R. (Eds). Logical structure and linguistic structure. Dordrechet: Kluwer, 1992. p.1-24.

ARIEL, M. Accessing NP antecedentes. London: Routledge, 1990.

BADECKER,W.; STRAUB, K. The processing role of structural constraints on the intepretation of pronouns and anaphora. Journal of Experimental Psychology: Learning, Memory and Cognition, v. 28, p. 748-769, 2002.

BARBOSA, P. Pro as a minimal NP. Ms. Universidade do Minho. 2014.

BARBOSA, P.; DUARTE, E.; KATO, M. Null subjects in european and Brazilian Portuguese. Journal of Portuguese Linguistics, v. 4, n. 2, p. 11-52, 2005.

BARKER, C. Possessive descriptions. Stanford: CSLI, 1995.

BURZIO, L. Weak anaphora. In: CINQUE, G.; KOSTER, J.; RIZZI, L.; ZANUTTINI, R. (Eds.). Paths towards Universal Grammar. Studies in honor of Richard S. Kayne. Washington, DC: Georgetown University Press, 1994, 59-84.

CALABRESE, A. Pronomina: Some properties of the Italian pronominal system. MIT Working Papers in Linguistics 8. Cambridge, MA: MIT. 1986.

CARDINALETTI, A.; STARKE, M. The typology of structural deficiency. A case study of the three classes of pronouns. In: van RIEMSDIJK, H. (Ed.), Clitics in the languages of Europe. Berlin: Mouton-De Gruyter, 1999. p. 145-233.

CARMINATI, M.-N. The Processing of Italian subject pronouns. Ph.D. Thesis, University of Massachusetts at Amherst, 2002.

CERQUEIRA, V. C. A Forma genitiva "dele" e a categoria de concordância (AGR) no Português do Brasil. In: KATO, M.; ROBERTS, I. (Eds.). Português Brasileiro: uma viagem diacrônica. Campinas: Editora da Unicamp, 1996. p. 129161.

CHIEN, Y-C.; WEXLER, K. Children's knowledge of Locality Conditions in Binding as Evidence for the Modularity of Syntax and Pragmatics. Language Acquisition, v. 1, p. 225-295, 1990.

CHOMSKY, N. Lectures in Government and Binding. Dordrecht: Foris, 1981.
Revista Letras,

Curitiba, UFPR,

n. 96, pp.461-486,

jul./dez. 2017.

ISSN 2236-0999

(versão eletrônica) 
CHOW, W. Y.; LEWIS, S.; PHILLIPS, C. Immediate sensitivity to structural constraints in pronoun resolution. Frontiers in Psychology, v. 5, p. 630, 2014.

COSTA, J.; AMBULATE. J. The acquisition of embedded subject pronouns in European Portuguese. In: INVERSON, M.; IVANOV; I.; JUDY, T.; ROTHMAN; J.; SLABAKOVA, R.; TRYZNA, M. (Eds.) Proceedings of the 2009 mind/context divide workshop. Sommerville, MA: Cascadilha Press, 2010. p.1-12.

DEN DIKKEN. M.; BERNSTEIN, J.; TORTORA, C.; ZANUTTINI, R. Data and grammar: means and individuals. Theoretical Linguistics, v. 33, n. 3, p. 335-352, 2007.

DUARTE, M. E. A perda do Princípio Evite Pronome no Português Brasileiro. Ph.D. Thesis, University of Campinas, Campinas, 1995.

DUARTE, M. E. Do pronome nulo ao sujeito pleno. In: KATO, M.; ROBERTS, I. (Eds.). Português Brasileiro: uma viagem diacrônica. Campinas: Editora da Unicamp, 1996. p. 107-128.

FERREIRA, M. Argumentos nulos em Português Brasileiro. MA Thesis, Campinas: University of Campinas, 2000.

FILIACI, F. Null and overt subject biases in Spanish and Italian: a cross-linguistic comparison. In: BORGONOVO, C.; ECHEVARRÍA, M.; PRÉVOST, P. (Eds.). Proceedings of the 12thHispanic Linguistic Symposium. Somerville, MA: Cascadilla, 2010. p. 171-182.

FLORIPI, S.; NUNES, J. Movement and resumption in null possessor constructions in Brazilian Portuguese. In: NUNES, J. (Ed) Minimalist essays on Brazilian Portuguese syntax. Amsterdam: John Benjamins Publishing, 2009. p. 51-68.

GROLLA, E. Pronouns as elsewhere elements: implications for language acquisition. Newcastle upon Tyne: Cambridge Scholars Publications, 2010.

HOLMBERG, A. Null subjects in Finnish and the typology of pro-drop. To appear in: TAMM, A.;VAINIKKA, A. (Eds.). Uralic syntax. Oxford: Oxford University Press, 2016.

HOLMBERG, A.; NAYUDU, A.; SHEEHAN, M. Three partial null subject languages: a comparison of Brazilian Portuguese, Finnish, and Marathi. Studia Linguistica, v. 63, p.: 59-97, 2009.

HOINENEN, T. Null subjects in Finnish: from either-or to more-or-less. Ms, Research Institute for the Languages of Finland, 1995.

HORNSTEIN, N. Move! A minimalist theory for construal. Oxford: Blackwell, 2001. 
C. Rodrigues \&

L. Dal Pozzo

Whose foot is

it? Pronominal

Possessives

in Pro-Drop

Languages:

An experimental

study

HORNSTEIN, N. Pronouns in minimal setting. In: COVER, N. NUNES, J. (Eds). The copy theory of movement. Amsterdam: John Benjamins, 2007. p. 351385.

HUHMARNIEMI, S.; BRATTICO, P. The Finnish possessive suffix. FinnoUgric Languages and Linguistics, v. 4, p. 2-41, 2015.

JURKA. J. The importance of being a complement of CED-effects revisited. Ph.D. Thesis, University of Maryland at College Park, 2010.

KANNO, K. The acquisition of null and overt pronominals in Japanese by English speakers. Second Language Research, v. 13, n. 3, p. 299-321, 1997.

MODESTO, M. Null Subjects without 'Rich' Agreement. Ph.D. Thesis, University of South California, Los Angeles, 2000.

MONTALBETTI, M. After binding. On the interpretation of pronouns. Ph.D. Thesis, MIT, Cambridge, 1984.

PÉREZ-LEROUX, A. T.; GLASS, W. R.. Null anaphora in Spanish second language acquisition: probabilistic versus generative approaches. Second Language Research, v. 15, n. 2, p. 220-249, 1999.

PIERREHUMBERT, J. The Finnish possessive suffixes. Language, v. 56, p. 603$621,1980$.

REINHART, T. Binding theory. In: WILSON, R. A.; KEIL, F. C. (Eds). The MIT encyclopedia of the cognitive sciences. Cambridge MA: MIT Press, 1999. p. $86-88$.

REINHART, T. Interface strategies: Optimal and costly computations. Cambridge MA: The MIT Press, 2006.

RIZZI, L. Null objects in Italian and the theory of Pro. Linguistic Inquiry, v. 17, p. 501- 57, 1986.

RODRIGUES, C. Impoverished morphology and A-movement out of Case domains. Ph.D. Thesis, University of Maryland at College Park, 2004.

RODRIGUES, C. Possessor raising through thematic positions. In: HORNSTEIN, N; POLINSKY, M. (Eds.). The movement theory of control. Amsterdam: John Benjamins, 2010. p. 119-146.

SAITO, M.; HOJI, H. Weak crossover and move in Japanese. Natural Language and Linguistic Theory, v. 1, p. 245-259, 1983.

SILVA, G. M DE O. Variação no sistema possessivo de terceira pessoa. Tempo Brasileiro, 78/79, p. 54-72, 1984.

Revista Letras,

Curitiba, UFPR,

n. 96, pp.461-486,

jul./dez. 2017.

ISSN 2236-0999

(versão eletrônica) 
SORACE, A.; FILIACI, F. Anaphora resolution in near-native speakers of Italian. Second Language Research, v. 22, n. 3. p. 339-368, 2006.

SPROUSE J.; SCHÜTZE, C. T.; ALMEIDA, D. A comparison of informal and formal acceptability judgments using a random sample from Linguistic Inquiry 2001-2010. Lingua, v. 134, p. 219-248, 2013.

TOIVONEN, I. The morphosyntax of Finnish possessive. Natural Language and Linguistic Theory, v.18, p. 579-609, 2000.

VAINIKKA, A. Genitive case in Finnish reconsidered. Biolinguistica Fennica working Papers, v. 2. p. 1-32, 2011.

VANIKKA, A.;Y. LEVI. Empty subjects in Finnish and Hebrew. Natural Language and Linguistic Theory, v. 17, p. 613-671, 1999.

VERGNAUD, J. R.; ZUBIZARRETA. M. L. The definite determiner and inalienable construction in French and English. Linguistic Inquiry, v. 23, p. 595652, 1992.

WASOW, T.; ARNOLD, J. Intuitions in linguistic argumentation. Lingua, v. 115, n. 11, p. 1481-1496, 2005.

Submetido em: 05-03-2017

Aceito em: 11-07-2017 